\title{
The Implications of Social Media on Local Media Business: Case Studies in Palembang, Manado and Bandung
}

\author{
ENI MARYANI \\ DETTA RAHMAWAN \\ SITI KARLINAH \\ Universitas Padjadjaran, Indonesia
}

\begin{abstract}
The implications of social media on the transformation of the media business are important issues in the study of the media industry. With the increasing penetration of the Internet in Indonesia and the proliferation of smartphone use, it is assumed that there are significant changes in media consumption patterns, especially for those who are often called millennials and generation Z. However, it is known that local media practitioners have yet to explore digital transformation properly, especially in terms of integrating social media platforms in various aspects of their business. This article used qualitative field research and observations to explore the perspectives of media practitioners in implementing social media in their business. Additional data were also collected from content analysis and exploration on all social media platforms owned by nine local media in Palembang, Manado, and Bandung. The result of the study revealed that the utilisation of social media is an innovation in the local media business, but it had not been optimally implemented. There is a disparity between the ideal expectations of social media use and the capabilities and knowledge of local media practitioners. In addition, the utilisation of social media in local media businesses has little impact on media income and the sustainability of the local media, since the context and ecosystem of the local media business are different from national media business located in Jakarta as the centre of economic activities in Indonesia.
\end{abstract}

Keywords: Local media, business models, media industry, business media, social media.

\section{INTRODUCTION}

The development of the media business in Indonesia offers a variety of opportunities as well as significant challenges. The development of information and communication technology has implications for the efficiency that occurs in the way media produce and distribute their content. One particular technology that not only affects the way in which the media operate their business but also changes the way the audience consumes media content is social media platforms (Nielsen \& Ganter, 2018; Wikström \& Ellonen, 2012). This has also happened in Indonesia, where the use of social media by Indonesian media audiences has continually increased from time to time (APJII, 2018; We Are Social, 2019). Economically, media business depends on two markets, namely audiences and advertisers, which both have influence over each other. Media content must attract a significant number of audiences as the first market. Furthermore, these audiences access and consume media content which will be sold as products to advertisers as a second market (Albarran, 2010). With that in mind, social media platforms have become important factors in the management of media business.

The media industry consists of three important institutions namely the media institution, research institution (such as Nielsen who produce TV ratings) and advertising institutions. Of the three institutions, the local media institutions face great challenges because research and advertising institutions in Indonesia have mainly been operating and concentrating in the capital city of Indonesia, Jakarta. Competition in the media industry, 
especially in the television and radio businesses, is highly dependent on Nielsen's rating which is perceived to represent the entire Indonesian population (while the rating actually does not represent all regions in Indonesia). Nielsen's data also has been the basis for collaboration and interaction between many brands and advertising agencies involved in the media and advertising industry without involving local media and local advertisers. Therefore, the local media must look for other sources of revenue other than advertisements that have mainly been concentrated at the national level. Referring to these conditions, local media management must be more creative in managing their business. The existence of social media is an important foundation as an added value for local media without being tied to the Nielsen's rating since it is easier to calculate the number of audience and their various engagements in social media.

At present, the local media have also made technological convergence in their businesses, one of which was related to the use of social media as part of their content distribution. Much of their content has been distributed through social media accounts and any access was made automatically recorded and can be used as a basis for calculating the estimated number of their online audiences. In addition, the increasing use of social media in Indonesia provides opportunities for local media managers to expand their audience to the younger generation of digital media users. In other words, the utilisation of social media in the way they operate is important for their sustainability and serves as opportunities to grow their business.

Local media business in Indonesia has so far experienced challenges from the dominance of the national media industry system. The idea to maintain and develop local media is also related to the context of Indonesian society which is diverse and covers a very wide area. The media industry in Indonesia cannot only be centered in Jakarta. Indonesia's media regulations after reform have basically sided with the idea. One of them is the Broadcasting Law No. 32/2002 which stipulates that Indonesia's national broadcasting system is run through networked broadcasting institutions and local broadcasting institutions (meaning that there should be no national broadcasting institutions). However, in practice, implementation is difficult because there are no operational guidelines and consistent law enforcement by regulators. Media ownership in Indonesia, which is oligarchic in nature, does not provide space for the development of local media in accordance with the mandate of the Law in terms of ownership, management, content distribution, etc. Furthermore, most of the media conglomerates agree that the networked broadcasting scheme is not profitable for their business.

The local media industry and local journalism practices that have proximity to local communities are one of the branches of media studies that are widely studied. However, studies on local media in Indonesia are still limited. Most popular studies related to the media industry in Indonesia are still focusing on the national media industry, using the political economy analysis of the media (Armando, 2016; Eriyanto \& Mutmainnah, 2018; Lim, 2012; Nugroho, Putri, \& Laksmi, 2012; Nugroho, Siregar, et al., 2012; Rahayu et al., 2015; Sudibyo, 2004; Tapsell, 2018). Whereas in other parts of the world as in the United States, Britain, and in various European and Scandinavian countries, studies related to media and journalism in a local scale, both regional and community-based is an important focus, even during the times of an increasingly globalised media industry (Nielsen, 2015). There are few studies on local media in Indonesia which highlight how local media operate and are being managed to withstand challenges both in terms of the management and the business. 
One of the keys focuses that is important to explore is related to how local media can survive amid various turbulences that hit the media industry, both caused by the constant change in the media business model and related to the growing dominance of "digital intermediaries" such as Google, Facebook, and aggregators that cut media revenue and reduced young people's interest in community news (Newman, Fletcher, Kalogeropoulos, \& Nielsen, 2019).

This study intends to be part of the ongoing research of the local media industry in Indonesia through a business perspective. More specifically, this article will explore how social media, as one of the crucial innovations in the media industry landscape, affect the local media business. This research was conducted on local media in three Indonesian cities; Palembang, Manado, and Bandung. Our research aims to convey: 1) How social media is being implemented as part of local media business management, and 2) What obstacles and opportunities arise as an implication of the use of social media in the local media business.

\section{LITERATURE REVIEW}

\section{The Conceptualisation and Development of Local Media}

Local media is an important part of the local community. Local media are media companies that are "owned by residents, locally produced, employs local residents as journalists, pay attention to the topic of news and the impact of the news locally, and read by local communities" (Franklin, 1998, p. xxi). A newspaper audience in a small town like York in the UK, or people in Denver, USA, for example, can only buy newspapers from local media companies that are in the place where they live, due to limited distribution coverage and newspaper circulation. In addition, in this context, local media is seen as an important part of local people's lives. This is especially related to the role of local media as a source of information for local residents, becoming the pillars of democracy and supervising local governance and politics, as well as related to the empowerment of local residents (Aldridge, 2007; Franklin, 1998; Nielsen, 2015).

In its development, various companies could "stop" being a local media company for various reasons such as the company's sales to other larger media companies. Consequently, important strategic decisions and the editorial rules previously done by local media companies were replaced by the decision of the holding company. Various assets of local media companies also become the property of the holding company, as a result, a variety of content production routines that require excess costs will be trimmed for efficiency. This includes reducing the level of routine local content production which requires reportage to local communities. Substantive changes related to local media and journalism occurred when the concept of media and journalism is seen solely from the business side, and not of its role in local communities (Franklin, 1998).

\section{Local Media Developments in Indonesia}

In Indonesia, the concept of local media was created from a plan to implement a networked broadcasting system, which according to Armando was first presented in the early discussion on the broadcast law in 1997 (Armando, 2016, p. 139). At the time, the discussion, which was conducted between progressive media practitioners, academics and several legislative members, proposed a concept of local media that should be able to build their own network and broadcast their content in a local context. Although this proposal was rejected, the 
momentum of Reformation revived the idea, along with the spirit of decentralised power and authority of the central government.

The concept of local media or local broadcasting institutions has been set forth in Indonesian broadcasting law No. 32/2002. Article 31 verse 1 reads "Broadcasting Stations that operate radio or television broadcasting services consist of network broadcasting station and/or local broadcasting station" which are centred on the expectation of a balance between the media companies based in Jakarta, with media companies located in other regions.

Indonesian Broadcasting law No. 32/2002 also forced national TV to limit their broadcast coverage. At that time, several national TV owners (SCTV, RCTI, MNC TV, Indosiar, Trans TV, Trans 7, TV One, and Metro TV) expressed their objections, although it was obvious that this was done to support the local broadcast stations and it was important for a healthy business climate. The law was also supposed to serve the efforts to make the media industry in Indonesia more democratic. After the draft of broadcasting law was approved by the legislative body and officially became the law, many of the Indonesian TV owners were organised using the name of the Indonesian Private Television Association and resisted the implementation of networked broadcast systems.

After the ratification of the Indonesian Broadcasting law, the application of local television-related frequency permits emerged, and local TV was immediately seen as a profitable form of business investment. In this context, local TV holdings have links to the existence of local conglomerates. For example, some televisions in central Java, such as Borobudur TV, are owned by businessmen in Central Java who have big businesses and capital power in the area. The same is also true in other regions. In Bali, for example, the media company Bali TV is also owned by the local conglomerate. Nevertheless, it does not take long for the media business tycoon in Jakarta, to sniff out potential gains and network expansion related to this local media business. In addition, investments in local television are also seen to "circumvent" the networked broadcast system. Consequently, many local media companies were successfully purchased by media entrepreneurs originating in Jakarta (Krisdinanto \& Supardi, 2018; Nugroho, Siregar, et al., 2012; Surokim, 2012; Yusuf, 2011). These practices also continue to occur because media regulation has more emphasis on the content of broadcasting and print industry, rather than on business models and the landscape of the media industry (Setianto, 2015).

\section{Social Media as Innovation in Local Media Business}

Various studies related to local media argued that the adaptation of digital technology on local media could be done to expand its concept especially towards young people (Ferguson \& Greer, 2016; Tang \& Lai, 2018). Furthermore, the implementation of various technological platforms in the local media can be viewed theoretically through the diffusion of innovations theory. Diffusion of innovations, which simply see how innovations are spread through particular channels, within a certain period of time, to a particular social system, offer a way to see how innovations are adapted by the local media (Rogers, 1995). Social media, in this case, is seen as an innovation, and local media can be put in the context of an organisation that function as a social system.

To be accepted by the local media audience, social media as innovation can be analysed through five aspects, 1) the relative advantage of social media, for example, the service is free, and promises the potential for audience expansion, 2) social media is also a technology that has compatibility within the media industry in general, 3) has been used in various levels of complexity, 4) the impact of innovation, in general, can be easily observed; 
and 5) social media usage patterns can be tested easily. The adoption of social media in the context of local media organisations can be done in a variety of contexts, such as whether the adoption is conducted through group consensus (such as the results of editorial meetings) or strategic direction by authority (e.g. from the owner or the largest shareholder of a local media). In the organisational context, diffusion of innovation also tends to see that the size of an organisation will correlate to the adoption of innovation, which means the larger the size of the company, the more innovative the company is. Nevertheless, in practice, innovations in the context of the media organisation will closely relate to the socio-economic aspect (Nielsen \& Ganter, 2018; Smyrnaios, Marty, \& Bousquet, 2015) and with socio-cultural factors (Kueng, 2017). Social media is an important part of the concept of media convergence which continues to evolve over time (Zotto \& Lugmayr, 2016). The rapid use of social media also fosters a large number of media users who mainly consume mobile media via their own smartphones, since mobile media have gained significant usage everywhere in everyday life (Westlund, 2013). With that in mind, local media practitioners surely need to pay special attention, especially in terms of managing content distribution in accordance with the context of mobile media usage. However, in certain contexts such as Indonesia, the adoption of digital media innovations is faced with the problem of infrastructure gaps (Lim, 2018) and face the uncertainty in terms of the regulation (Nugroho, Siregar, et al., 2012). In other words, the analysis related to the implications of social media remains connected with other internal and external factors encompassing the media industry in Indonesia (Maryani, Karlinah, \& Rahmawan, 2018).

\section{METHODOLOGY}

First, field research from 2017 to 2018 was conducted as a preliminary study related to local media to examine media policy and the sustainability of local media in Indonesia (Maryani et al., 2018). Findings from the field research were then re-explored by adapting the web content analysis method (Herring, 2009; Holcomb, 2018) to nine local media in Bandung, Palembang, and Manado as the context of this research. The selection of locations and research objects is done through two stages.

During the first stage, purposive sampling was done by dividing Indonesia into three areas, namely the west, central, and east areas. Then the data related to media company were taken from the National Press Data 2015 (Press Council, 2015), which were then processed manually to see which areas have the greatest number of media companies. At this stage, taking into consideration the spread of the location, we found that South Sumatera (83 media companies) and North Sulawesi (62 media companies) are two areas outside Java with the greatest number of media companies. As for representatives from Java Island, we chose West Java (129 media companies) based on consideration of its proximity to the centre of the Indonesian media industry (DKI Jakarta). Next, we set the city of Bandung as a representative of West Java, Palembang as a representative of South Sumatera, and the city of Manado as a representative of South Sulawesi.

For the second stage of this research, web content analysis, purposive sampling was conducted based on the verified media company data from the Press Council (2018), which can be accessed at https://dewanpers.or.id/data/perusahaanpers. We chose three media from each of the three regions $(n=9)$. Points of consideration in the selection of the media are: in one research location, there must be differences in the type of media related to its status as local media or networked local media, as well as from the type of media content. 
Preliminary observations also considered the local media consistency in terms of their digital platforms' management. Hence, some of the media that are inactive were excluded from data collection phases. Finally, the local media selected to be the object of our content analysis are PRFM, KompasTV Jabar, Pikiran Rakyat (West Java), Seputarsulut.com, ManadoToday, Tribune Manado (North Sulawesi), SriwijayaPost, SriwijayaTV, and Sumatera Ekspress (South Sumatera).

The content analysis was conducted from May to October 2019 on the website of the local media and various social media (Facebook, Twitter, Instagram, YouTube) owned by local media. All data collection procedures started with Google's search engine. Web content analysis looked at 1) Any social media used by each local media, 2) The performance of the local media (seen from available metrics); and 3) If there was any potential income from social media that they used. Data obtained in this study underwent qualitative analysis and therefore cannot be claimed for generalisation of the complexity of the local media industry in Indonesia.

\section{RESULTS AND DISCUSSION}

Adaptations of social media in the media industry can be seen as the logical consequence when looking at the fact that millennials and generation $\mathrm{Z}$ in Indonesia are loyal users of various social media in their daily lives (We Are Social, 2019). This is also related to global trends that the use of digital media and social media as a source of information is sharply increasing (Newman et al., 2019). However, this is not directly proportional to the search for information or official news from the mainstream media. There is even a tendency that more information and hard news are abandoned by young people because they prefer a variety of news with a more popular, concise and "soft" styles (Ferguson \& Greer, 2016; Newman et al., 2019; NiemanLab, 2018).

In Indonesia, many surveys concluded that television remains the main source of information for most of the Indonesian population (Indotelko, 2018; Lembaga Survei Kedai Kopi, 2018). It has also been argued that mainstream online media in Indonesia are subjected to the media logic that prioritise the most effective metrics such as traffic, clicks and pageviews which promotes manipulative practices such as click baiting and sensationalism (Wijaya, 2019). The problem is then, of course, the extent to which the media organisation considers how social media is part of their future strategy to reach a new, younger audience, who are very close to technological innovations, have many options related to their media consumption, and are also more selective in looking for information.

Some news related to media investments in Indonesia on social media can be seen on the Bakrie group's investments in Path, which has now ceased to operate (Franedya, 2018), Emtek's investment in Blackberry Messenger, which has also closed its services, and the cooperation of MNC Group with WeChat (Anggit, 2018). Some of the examples that have been described above show how strategic investments are mostly done in large national media groups that have strong capital power and only aimed at business development and economic background, rather than to strengthen the overall media industry (Tapsell, 2018).

In this article, local media in Indonesia refers to networked local media and "pure" local media that are not owned by national media based in Jakarta. We do not limit our analysis to only local newspapers on the grounds that competition in the media business is now multiplatform. In addition, we also want to see whether there are any differences between various kinds of media platforms (be it television, radio, or newspaper) in implementing innovations related to social media in their business operations. 


\section{Social Media use in Local Media Management}

The willingness to adapt digital technology is the basis of social media usage by media institutions. A local media manager who has been interviewed in the study said that the adaptation of digital technology, including social media, has been deemed important, but has not been seriously followed by the entire management. In addition, it is acknowledged that the adaptation of digital technology in the context of local media is quite lagging behind when compared to the adaptation practices done by the national media as being argued by one of the respondents:

We invite media activists... To give perspective from social media and online viewpoint... What I see is that many [managers] are not serious [in adapting to digital technology] and switching to digital. They are very relaxed because they have not felt pressed. [Our company] recently created websites just about 3 years ago and the website is only seen as the extension of the newspaper and not properly managed (Informant PR).

One of the respondents said that social media adaptations are highly dependent on the trend. For example, in 2008-2009, while many people used Facebook, many local media managers saw that Facebook could be used for various objectives, one of which was for developing the concept of citizen journalism. The concept of citizen journalism also helped the establishment of a good relationship between audiences and media companies. One that changed, for example, is how the audiences, which previously could only make contact with the media via telephone and SMS could now use Facebook. Later, when various platforms other than Facebook began to be popularised, these local media practitioners immediately adopted the platform. Examples can be seen in PRFM media in Bandung, which utilised Twitter and WhatsApp optimisation as channels for reports and complaints from the community. On the other hand, the strategic use of social media is related to the distribution of content more broadly. This can be seen in local media that also networked with national media, as done by local media that networked with Kompas Group (Sonora, Tribun), and Jawa Pos Group (Sumatera Ekspress).

Now we are using three social media; Twitter, Facebook, and Instagram. Our Website exists, but usually for those who want to stream. For information, we link to tribunjabarnews.com and Sonora's Twitter...We take only accountable sources. [since] We are part of the Kompas and Tribun group we usually use these two media as our source of information (Informant SN).

The concept of citizen journalism through social media as well as the process of distributing content through social media optimization, can increase the level of interaction that occurs between citizens with local media. However, this turned out to be less of an impact on the local media business as a whole. Some local media practitioners acknowledge that the amount of metrics available is not necessarily correlated with improving overall business performance. For example, for PRFM as local radio, the number of followers on Facebook, Twitter, and Instagram do not necessarily increase the number of listeners on the radio. In addition, in terms of business, the use of social media also does not necessarily have 
a significant impact on the media business. Furthermore, when viewed in terms of additional potential revenue, the income from online media and social media still cannot rival the income obtained conventionally. One of the local media practitioners, for example, says that revenues from online media and social media only revolve around $5 \%$ to $10 \%$ of their total revenue. Nonetheless, the perception of "revenue" on social media is also still limited to ad revenues. In other words, local media practitioners still don't have the ability to use social media to increase media revenue.

This shows that there is a gap in the knowledge of local media managers, especially non-networked local media, related to the social media potential that should be explored more creatively, such as by configuring native advertising system, content marketing, and so forth (Ferguson \& Greer, 2016; Holcomb, 2018). On the other hand, although some local media practitioners claim to have tried several attempts to conduct social media training externally, they see it has no significant impact. For example, some practitioners do not really understand the concept of KPI (key Performance indicator) and how to measure successful social media strategies. Non-networked local media practitioners also think that the owner of the media does not think of making prolonged strategic investments. This is a contrast when compared to local media that already has a network with national media such as Kompas Group and Jawa Pos Group. Local Media networks such as TribunManado (Kompas group) and Sumatera Ekspress (Jawa Pos Group) have better systems and concepts of social media implementation in management because they are supported by the capital of their owners in Jakarta. Hence, in some cases, the performance and consistency of their social media management are better than the non-networked local media. Some networked local media have regular training, which is managed by their national media counterparts. Some local media managers are sent to Jakarta to attend the training at the head office or join remote training using various applications such as video call or teleconference.

\section{Social Media Performance Analysis}

Content analysis was conducted on nine local media, PRFM, KompasTV and Pikiran Rakyat (West Java), Seputarsulut.com, ManadoToday, Tribune Manado (North Sulawesi), SriwijayaPost, SriwijayaTV, and Sumatera Ekspress (South Sumatera). At first, we hoped to have at least local radio, local television, local newspapers, and local online media. However, after the initial inspection, not all local media have a consistent digital presence. Content analysis was done from May to October 2019. The results are described in a simple data tabulation form.

Table 1: Platforms used by the Local Media

\begin{tabular}{cll}
\hline No. & \multicolumn{1}{c}{ Local Media } & \multicolumn{1}{c}{ Social Media } \\
\hline 1 & PRFM & Twitter, Facebook, Instagram, YouTube \\
2 & KompasTVJabar & Twitter, Instagram, YouTube \\
3 & Pikiran Rakyat & Twitter, Facebook, Instagram, YouTube \\
4 & SmartFM Manado & Twitter, Facebook, Instagram, YouTube \\
5 & ManadoToday & Twitter, Facebook, Instagram \\
6 & Tribun Manado & Twitter, Facebook, Instagram, YouTube \\
7 & SriwijayaPost & Twitter, Facebook, Instagram, YouTube \\
8 & SriwijayaTV & Twitter, Facebook, Instagram, YouTube \\
9 & Sumatera Ekspres & Twitter, Facebook, Instagram, YouTube \\
\hline
\end{tabular}


Table 1 above shows the types of platforms used by the local media. This selection is related to the trend of social media usage in Indonesia. The report from We Are Social for example, shows that as of 2019 , all the social media mentioned above still have a considerable number of users, so it can be understood that various media choose to use those platforms to reach their audiences.

Data collection procedures started with search in Google's search engine, which then leads to the main site of each local media. In cases where there were some local media that did not provide social media links on the main site, we re-conducted search through the search engines by adding social media keywords after the local media (e.g. "SmartFM Manado" and "Instagram "). The analysis of some metrics that can represent the performance of social media is adapted from previous research (Ferguson \& Greer, 2016; Holcomb, 2018) and added with observations related to "level of activity" of social media, in which case a local media is considered very active when they publish content more than once a day, and inactive if they do not publish content in more than one month. Data tabulation related to the summary of local media's social media performance can be seen in Tables 2 to 5 below.

Table 2: Twitter Performance

\begin{tabular}{|c|c|c|c|c|c|c|}
\hline No. & Local Media & Twitter Account & $\begin{array}{l}\text { Year of } \\
\text { account } \\
\text { creation }\end{array}$ & $\begin{array}{c}\text { Number } \\
\text { of } \\
\text { tweets }\end{array}$ & $\begin{array}{c}\text { Number } \\
\text { of } \\
\text { followers }\end{array}$ & $\begin{array}{l}\text { Level of } \\
\text { Activity }\end{array}$ \\
\hline 1 & PRFM & @PRFMnews & June 2010 & 593,205 & 237,506 & Very active \\
\hline 2 & KompasTVJabar & @kompastv_jabar & $\begin{array}{c}\text { October } \\
2010\end{array}$ & 14,820 & 3879 & Inactive \\
\hline 3 & Pikiran Rakyat & @pikiran_rakyat & July 2009 & 251,531 & 409,434 & Very active \\
\hline 4 & $\begin{array}{l}\text { SmartFM } \\
\text { Manado }\end{array}$ & $\begin{array}{c}\text { @SmartFM_Mana } \\
\text { do }\end{array}$ & $\begin{array}{c}\text { February } \\
2012\end{array}$ & 30,401 & 2124 & Active \\
\hline 5 & ManadoToday & @Manado_Today & $\begin{array}{c}\text { February } \\
2010\end{array}$ & 66,459 & 11,812 & Active \\
\hline 6 & Tribun Manado & @Manado_Today & June 2010 & 209,532 & 77,629 & Very active \\
\hline 7 & SriwijayaPost & @sripoku & $\begin{array}{l}\text { August } \\
2009\end{array}$ & 174,876 & 30,797 & Very active \\
\hline 8 & SriwijayaTV & @sriwijayatv & $\begin{array}{c}\text { January } \\
2012\end{array}$ & 19,494 & 2588 & Less active \\
\hline 9 & Sumatera Ekspres & @koransumeks & June 2012 & 63,953 & 10,383 & Very active \\
\hline
\end{tabular}

Table 3: Facebook performance

\begin{tabular}{|c|c|c|c|c|c|c|}
\hline No. & Local Media & $\begin{array}{l}\text { Facebook } \\
\text { Account }\end{array}$ & $\begin{array}{l}\text { Year of } \\
\text { account } \\
\text { creation }\end{array}$ & Likes & $\begin{array}{c}\text { Number } \\
\text { of } \\
\text { followers }\end{array}$ & Level of activity \\
\hline 1 & PRFM & $\begin{array}{c}\text { @PRFMNewsCha } \\
\text { nnel }\end{array}$ & April 2012 & 71,754 & 74,096 & Very active \\
\hline 2 & KompasTVJabar & - & - & - & - & - \\
\hline 3 & Pikiran Rakyat & $\begin{array}{l}\text { @pikiranrakyaton } \\
\text { line }\end{array}$ & April 2010 & 247,530 & 247,593 & Very active \\
\hline 4 & SmartFM Manado & @1012smartfm & $\begin{array}{l}\text { March } \\
2016\end{array}$ & 475 & 487 & Inactive \\
\hline 5 & ManadoToday & @Manado_Today & July 2010 & 9498 & 9491 & Very active \\
\hline 6 & Tribun Manado & @tribun.manado & $\begin{array}{c}\text { February } \\
2009\end{array}$ & 167,435 & 179,675 & Very active \\
\hline
\end{tabular}




\begin{tabular}{|c|c|c|c|c|c|c|}
\hline 7 & SriwijayaPost & @sripoku & $\begin{array}{c}\text { March } \\
2009\end{array}$ & 283,031 & 301,247 & Very active \\
\hline 8 & SriwijayaTV & @sriwijayatv & $\begin{array}{c}\text { January } \\
2011\end{array}$ & 9199 & 10,301 & Active \\
\hline 9 & Sumatera Ekspres & @koransumeks & $\begin{array}{c}\text { December } \\
2013\end{array}$ & 6946 & 7390 & Very active \\
\hline
\end{tabular}

Table 4: Instagram performance

\begin{tabular}{llllll}
\hline No. & \multicolumn{1}{c}{ Local Media } & \multicolumn{1}{c}{ Instagram Account } & \multicolumn{1}{c}{ Posts } & $\begin{array}{c}\text { Number of } \\
\text { followers }\end{array}$ & $\begin{array}{c}\text { Level of } \\
\text { Activity }\end{array}$ \\
\hline 1 & PRFM & @prfmnews & 29,047 & 138,299 & Very active \\
2 & KompasTVJabar & @kompastvjabar & 73 & 762 & Inactive \\
3 & Pikiran Rakyat & @ pikiranrakyat & 2694 & 65,408 & Very active \\
4 & SmartFM Manado & @ 1012smartfm & 3232 & 1144 & Active \\
5 & ManadoToday & @manadotodaycom & 28 & 69 & Inactive \\
6 & Tribun Manado & @tribun_manado & 5896 & 19,621 & Active \\
7 & SriwijayaPost & @sripoku & 14,386 & 142,284 & Very active \\
8 & SriwijayaTV & @sriwijayatv & 1343 & 5628 & Active \\
9 & Sumatera Ekspres & @sumateraekspres & 3476 & 7390 & Very active \\
\hline
\end{tabular}

Table 5: YouTube Performance

\begin{tabular}{|c|c|c|c|c|c|c|}
\hline No. & Local Media & $\begin{array}{l}\text { Year of account } \\
\text { creation }\end{array}$ & Uploads & Subscribers & Views & $\begin{array}{l}\text { Level of } \\
\text { activity }\end{array}$ \\
\hline 1 & PRFM & Agustus 2018 & 81 & 29,047 & 138,299 & Active \\
\hline 2 & KompasTVJabar & Maret 2015 & 6960 & 10,300 & $3,342,637$ & $\begin{array}{l}\text { Very } \\
\text { active }\end{array}$ \\
\hline 3 & Pikiran Rakyat & Februari 2016 & 227 & 9500 & $2,553,836$ & $\begin{array}{l}\text { Very } \\
\text { active }\end{array}$ \\
\hline 4 & $\begin{array}{l}\text { SmartFM } \\
\text { Manado }\end{array}$ & Desember 2015 & 4 & 6 & 249 & Inactive \\
\hline 5 & ManadoToday & November 2010 & 2 & 18 & 1019 & Inactive \\
\hline 6 & Tribun Manado & September 2019 & 178 & 581 & 146,177 & Active \\
\hline 7 & SriwijayaPost & September 2015 & 1226 & 4020 & 2,971,281 & Inactive \\
\hline 8 & SriwijayaTV & Juli 2012 & 8894 & 35,400 & $13,452,523$ & $\begin{array}{l}\text { Very } \\
\text { active }\end{array}$ \\
\hline 9 & $\begin{array}{l}\text { Sumatera } \\
\text { Ekspres }\end{array}$ & Desember 2018 & 449 & 17,200 & $3,433,526$ & $\begin{array}{l}\text { Very } \\
\text { active }\end{array}$ \\
\hline
\end{tabular}

Referring to the tables, it can be said that social media usage by the local media is quite active and generate fairly large groups of followers. Companies that have produced more than 10,000 posts generally have active performance. Facebook performance from printed media in three areas are not much different; Manado $(179,675)$, Bandung $(247,593)$ and Palembang $(301,247)$. This performance also confirms that the performance of social media is not very much determined by the geographical centre (Java) and the periphery (Sulawesi and Sumatra). Facebook's performance in the media in Palembang was very active in all types of media studied.

Instagram's performance in Palembang is relatively active while in Bandung and Manado there are those that were inactive. Instagram's striking performance shows far more coverage than other social media. Moreover, it can be said that a YouTube account can be seen by millions of people, even Sriwijaya TV's YouTube account has more than 13 million views. 
Based on the performance of social media used in the City of Manado, Bandung, and Palembang, it can be concluded that YouTube is a media that is quite popular for local media in the city of Bandung and Palembang. Tens of millions of people view Sriwijaya TV's YouTube account, while Kompas TV which has an inactive performance on other social media, has a YouTube account that has hit more than 3 million audiences.

\section{Obstacles and Opportunities in Social Media Usage}

Our analysis shows that the use of social media by local media in Bandung, Manado and Palembang has started since at least 2009, although there are also local media that just started to use social media in 2019. Twitter and Facebook are two social media that have been used since 2009. The newspaper Pikiran Rakyat (Bandung) uses Twitter with the username @pikiran_rakyat and the newspaper Sriwijaya Post (Palembang) uses Twitter with the username @sripoku. In the same year, Tribun Manado and Sriwijaya Post also started using Facebook. Both are well-known newspapers in Manado and Palembang. In the period of 2010-2012 other local media, radio and TV in Palembang, Bandung and Manado also began to use Twitter. Referring to the data, it can be said that print media is faster in adapting the use of social media. The first YouTube users are local television in Manado, Manado Today and Sriwijaya TV in Palembang. However, Manado Today's YouTube account was then inactive and only briefly uploaded two items. On the other hand, Sriwijaya TV uses YouTube very actively and has uploaded 8,894 content and has been seen by more than 13 million viewers.

Looking at the existing trends, Instagram and YouTube are the next social media which will be optimised, although the way to manage these two social media will be slightly different from Twitter and Facebook. The different levels of social media activity might be caused by 1 ) the absence of resources; and 2) the fact that there are no significant results from the use of such social media. The results of data analysis also showed that in terms of visual content, networked local media have an advantage in the consistency of content management. On one hand, for local media networks, it can be assumed that they have an advantage because various directives and strategic plans have been given by the holding company but on the other hand, this can be an obstacle when the strategic plan does not match or does not have a good impact on the development of the media business in the local context.

Advertising is still minimal and advertising content is found mostly on Instagram, but audience interactions with advertising content are minimal compared to other local media content. More in-depth analysis is needed to see how effective social media placings are, and whether advertisers in the context of local media already have adequate knowledge on ROI (Return of Investment) and KPI (Key Performance Indicator) as an important concept in digital advertising. On the other hand, it should also be further researched whether the marketing people in each local media has a strategic plan in the field of digital marketing since the data shows that even in the context of Jakarta, there are still knowledge gaps among digital business practitioners (GetCraft, 2018).

Based on the results of the study it can be concluded that the change in media consumption patterns from conventional to digital media has not been anticipated well by the local media business in Indonesia. Through social media platforms, conventional local media (newspapers, radio, television) can reach a wider new audience. Furthermore, local media are also able to obtain accurate data related to the audience that accesses them. Through this audience data, ideally, local media could increase their advertisement 
acquisition. However, it is known that the successful use of social media in the local media business model in the three cities studied are highly dependent on the perceptions and assumptions of local media practitioners rather than based on real evidence and data.

Local media practitioners need to have a better social media management strategy based on data related to contextual local conditions. Research strategies for collecting local media audience data, satisfaction surveys, etc. are urgently needed. This issue also relates to the perception of local media managers who see that social media management is only related to the technical skills of its workers rather than requiring in-depth assessments. In other words, people who work on social media in local media are often only regarded as administrators, and not as people who have to think about social media strategies broadly within the organisational context (Looy, 2016) and in relation to the media business as a whole.

In addition, other than the four platforms that have been studied, there are still other opportunities to explore and optimise various instant messaging applications that are very popular in Indonesia such as WhatsApp and Line. These two platforms are not included in the platforms that are being optimised by local media in Indonesia. In fact, these instant messaging applications can be used as one of the new creative tools for content distribution. For example, local media managers can have multiple WhatsApp accounts devoted to sending newsletters every morning to their readers. It is certainly a noteworthy opportunity considering that various other countries such as Brazil, Malaysia, and some African countries, instant messaging applications are starting to be used in conjunction with social media use (Newman et al., 2019).

The results of the study also show that local media practitioners still use one-way communication and interaction styles rather than using creative two-way interaction. Different examples can be seen from the implementation of the concept of "citizen journalism" on the PRFM radio Bandung, and how audience engagement and relationships are performed to reinforce the "sense of community". In fact, this should be one of the advantages of local media, which is related to proximity or close distance between the local media with the audience. The concept of the locality should be better optimised, and social media should be able to bridge the media with their audiences. Opportunities related to the use of social media by local media as a two-way information exchange, as well as for informing the local residents with solutions to their everyday problems deserve to be considered.

\section{CONCLUSION}

Increasing Internet penetration in Indonesia encourages a significant increase in social media usage. In addition to the proliferation of smartphone usage, it also changes the pattern of media consumption, especially for millennials and generation Z (Ferguson \& Greer, 2016; Nielsen \& Ganter, 2018). The results of our study show that the use of social media by some media can reach substantial audiences. However, success depends greatly on the efforts made by local media practitioners. There are media that consistently work on social media and can manage their audiences that have the potential to continually be developed well as being seen from the use of YouTube by local media in Bandung and Palembang. Nevertheless, this opportunity does not appear to be carried out by the local media in Manado. The greatest potential can be seen on how the print and broadcasting media increase its reach to digital audiences through YouTube. 
The awareness of local media practitioners toward opportunities to reach digital audiences has developed but in general social media management has not been optimal or is still lacking. This condition is caused by the gap between awareness and ideal expectations related to the use of social media, with the knowledge and ability to manage social media in each local media. The gap is not only at the operational level but also at the level of policy makers. Media that have relatively good management of social media are media that have leaders who are able to encourage the optimisation of the use and management of social media with the policies they set. Policy in the budget aspect is very influential on the development of digital technology used while policies in the field of human resources also affect the role or position given to the managers of social media as well as increasing competencies provided through various training. In addition to the limited knowledge and skills of practitioners managing social media, the leadership level policies related to optimising the use of social media become a challenge for local media.

Another challenge is the lack of a strategy carried out towards the target, in this case, the digital audience. This study also sees that the use of social media can not only be used to reach a wider audience but must also be able to develop strategies for managing relations between local media and their audiences. Social media as an interactive media places the user in a relatively free and dynamic position. Therefore, their attention and ties to the local media must also be maintained intensively and with an interactive communication model.

It can be said that social media is an innovation in the local media business model in terms of converging technology and media content on various platforms. With social media, the local media content could reach a wider new audience. It is also possible to obtain accurate data related to the audience. Based on these data from social media, there are opportunities to increase revenue from advertisements. However, this research sees that the implications of social media in the local media business model in the three cities studied are highly dependent on the management of social media carried out by the leaders of each local media.

The results of the study show that the management of social media still depends on the perceptions and assumptions of local media practitioners rather than based on real evidence and research data. This can be one factor that causes no correlation between social media usage and an increase in media income. Hence, the significance of social media is not yet felt for the sustainability of the local media business. Therefore, more creative efforts are needed to collaborate with the use of local media with various applications in digital media including instant messaging applications. In other words, local media managers are required to be more open to new ideas of social media management, and to allocate more resources to manage it. This is not only related to content management but includes utilising data from social media that is used for more strategic purposes and developing new business models. 


\section{ACKNOWLEDGEMENT}

This research was carried out with funding from the Ministry of Research, Technology and Higher Education, Indonesia (2017-2019), and with support from the Faculty of Communication Science, Universitas Padjadjaran.

\section{BIODATA}

Dr. Eni Maryani is a Lecture and the Head of center for study of Communication, Media, and Culture at Universitas Padjadjaran. Eni focuses on the critical perspective of communication and media. Her research interests are in the field of media related to the media industry, media literacy, and gender Email: eni.maryani@unpad.ac.id

Detta Rahmawan, MA. is a lecturer at the Communication Management department, Faculty of Communication Science, Universitas Padjadjaran. His research interest is critical perspective on digital media industry and disinformation ecosystem. Email: detta@unpad.ac.id

Dr. Siti Karlinah is a lecturer at the Journalistic department, Faculty of Communication Science, Universitas Padjadjaran. Her research is mainly focused on Journalism, Mass Communication, and Health Communication. Email: skarlinah@unpad.ac.id 


\section{REFERENCES}

Albarran, A. B. (2010). The media economy. New York: Routledge.

Aldridge, M. (2007). Understanding the local media. Berkshire: Open University Press.

Anggit, I. (2018). Dari WeChat hingga Go-Jek, Ini gurita bisnis tencent di RI. CNBC Indonesia. Retrieved on October 20, 2019, from https://www.cnbcindonesia.com/tech/20181114110210-37-42065/dari-wechathingga-go-jek-ini-gurita-bisnis-tencent-di-ri

APJII (Asosiasi Penyelenggara Jasa Internet Indonesia). (2018). Penetrasi \& profil perilaku pengguna Internet Indonesia. Retrieved from https://apjii.or.id/survei2018s

Armando, A. (2016). Televisi Indonesia - Di bawah kapitalisme global. Jakarta: Kompas Media Nusantara.

Eriyanto, \& Mutmainnah, N. (2018). Indonesia - Media landscape. Retrieved from https://medialandscapes.org/country/indonesia

Ferguson, D. A., \& Greer, C. F. (2016). Reaching a moving target: How local TV stations are using digital tools to connect with generation C. International Journal on Media Management, 18(3-4), 1-20. doi: 10.1080/14241277.2016.1245191

Franedya, R. (2018). Cerita keluarga Bakrie di balik Path. CNBC Indonesia. Retrieved on October 21, 2019, from https://www.cnbcindonesia.com/tech/20180917180240-3733525/cerita-keluarga-bakrie-di-balik-path

Franklin, B. (Ed.). (1998). Local journalism and local media. London: Routledge.

GetCRAFT. (2018). Indonesia native advertising and influencer marketing report 2018. Retrieved from https://academy.getcraft.com/indonesia-native-advertising-andinfluencer-marketing-report-2018

Herring, S. C. (2009). Web content analysis: Expanding the paradigm. In J. Hunsinger, L. Klastrup, \& M. Allen (Eds.), International handbook of Internet research (pp. 233-249). Retrieved from http://link.springer.com/chapter/10.1007/978-1-4020-9789-8_14

Holcomb, J. (2018). Digital adaptation in local news. Columbia Journalism Review. Retrieved from https://www.cjr.org/tow_center_reports/digital-adaptation-in-local-news.php/

Indotelko. (2018). Media digital dan konvensional saling melengkapi. Retrieved on October 18, 2019, from https://www.indotelko.com/read/1520903878/media-digitalkonvensional

Kueng, L. (2017). Going digital: A roadmap for organisational transformation. Reuters Institute for the Study of Journalism. Retrieved from https://reutersinstitute.politics.ox.ac.uk/our-research/going-digital-roadmaporganisational-transformation

Krisdinanto, N., \& Supardi, A. (2018). The Bourdieuan triangle of journalism, political and economic fields: Brief milestones of Indonesian journalism in Surabaya. Jurnal Komunikasi: Malaysian Journal of Communication, 34(3), 115-130. doi: 10.17576/JKMJC-2018-3403-07

Lembaga Survei Kedai Kopi. (2018). Survei nasional opini publik 2018. Retrieved from http://www.kedaikopi.co/web/images/Survey_Nasional_Opini_Publik_April_2018.p df

Lim, M. (2012). The league of thirteen: Media concentration in Indonesia. Participatory Media Lab. 
Lim, M. (2018). Dis/Connection: The co-evolution of sociocultural and material infrastructures of the Internet in Indonesia. Indonesia, 105(April 2018), 155-172.

Looy, A. V. (2016). Social media management: Technologies and strategies for creating business value. Cham: Springer International Publishing.

Maryani, E., Karlinah, S., \& Rahmawan, D. (2018). The sustainability of local media within the domination of national media industry. E3S Web of Conferences, 73, 14010. doi: $10.1051 /$ e3sconf/20187314010

Newman, N., Fletcher, R., Kalogeropoulos, A., \& Nielsen, R. K. (2019). Reuters Institute digital news report 2019. Reuters Institute for the Study of Journalism. Retrieved fromhttp://www.digitalnewsreport.org/

Nielsen, R. K. (Ed.). (2015). Local journalism: The decline of newspapers and the rise of digital media. London: I.B Tauris.

Nielsen, R. K., \& Ganter, S. A. (2018). Dealing with digital intermediaries: A case study of the relations between publishers and platforms. New Media \& Society, 20(4), 1600-1617. doi: $10.1177 / 1461444817701318$

NiemanLab. (2018). From news fatigue to news avoidance. Retrieved on October 21, 2019, from https://www.niemanlab.org/2018/12/from-news-fatigue-to-news-avoidance/

Nugroho, Y., Putri, D. A., \& Laksmi, S. (2012). Memetakan lansekap industri media kontemporer di Indonesia. Jakarta: Centre for Innovation Policy and Governance.

Nugroho, Y., Siregar, M. F., \& Laksmi, S. (2012). Memetakan kebijakan media di Indonesia. Jakarta: Centre for Innovation Policy and Governance.

Press Council. (2015). Data pers nasional 2015. Dewan Pers. Retrieved from www.dewanpers.or.id

Rahayu, Wahyono, B., Rianto, P., Kurnia, N., Wendratama, E., \& Siregar, A. E. (2015). Menegakkan kedaulatan telekomunikasi dan penyiaran di Indonesia. Yogya: PR2Media \& Tifa.

Rogers, E. M. (1995). Diffusion of innovations (5th ed.). New York: Free Press.

Setianto, Y. P. (2015). Media policy in the context of global media flows, the Internet, and piracy: An historical analysis of media regulation in Indonesia. Jurnal Komunikasi: Malaysian Journal of Communication, 31(2), 371-388. doi: 10.17576/jkmjc-20153102-21

Smyrnaios, N., Marty, E., \& Bousquet, F. (2015). Between journalistic diversity and economic constraints: Local pure players in southern France. In R. K. Nielsen (Ed.), Local journalism: The decline of newspapers and the rise of digital media. London: I.B Tauris.

Sudibyo, A. (2004). Ekonomi politik media penyiaran. Jakarta: Institut Studi Arus Informasi (ISAI) dan Lembaga Kajian Islam dan Sosial Jakarta.

Surokim. (2012). Ekonomi politik media penyiaran lokal. Yogyakarta: Interpena.

Tang, T., \& Lai, C. (2018). Managing old and new in local newsrooms: An analysis of generation C's multiplatform local news repertoires. Journal of Media Business Studies, 15(1), 42-56. doi: 10.1080/16522354.2018.1459141

Tapsell, R. (2018). Kuasa media di Indonesia: Kaum oligarki, warga, dan revolusi digital. Serpong, Tangerang Selatan: Marjin Kiri.

We Are Social. (2019). Digital 2019: Indonesia. datareportal.com. Retrieved from https://datareportal.com/reports/digital-2019-indonesia?rq=indonesia

Westlund, O. (2013). Mobile news: A review and model of journalism in an age of mobile media. Digital Journalism, 1(1), 6-26. doi: 10.1080/21670811.2012.740273 
Wijaya, B. S. (2019). Dancing with the impropriety of media: How indonesian consumers think and behave towards the unethical and illogical online news. Jurnal Komunikasi: Malaysian Journal of Communication, 35(1), 187-205. doi: 10.17576/JKMJC-20193501-13

Wikström, P., \& Ellonen, H. K. (2012). The impact of social media features on print media firms' online business models. Journal of Media Business Studies, 9(3), 63-80. doi: 10.1080/16522354.2012.11073552

Yusuf, I. A. (2011). Media lokal dalam konstelasi komunikasi politik di daerah. Jurnal IImu Sosial Dan Ilmu Politik, 14(3). Retrieved from https://jurnal.ugm.ac.id/jsp/article/view/10930

Zotto, C. D., \& Lugmayr, A. (2016). Media convergence as evolutionary process. In A. Lugmayr \& C. D. Zotto (Eds.), Media convergence handbook - Vol. 2: Firms and user perspectives (pp. 3-16). Berlin, Heidelberg: Springer-Verlag 